\title{
Museums as agents and settings for climate hope
}

\author{
Sarah W. Sutton
}

\begin{abstract}
Despite the uneven distribution of the impacts of climate change, much of the World's population commonly encounters climate change evidence either directly or indirectly. For many, the dread of a slow-onset disaster of such proportions can be overwhelming. As the emotional effects of climate change appear across society, some people are driven to action, some to inaction or paralysis. Museums could be key agents in turning these emotions into action and hope, but the work is new and the research uneven. The author describes her experience of the intersection of museum work and public emotions on climate change by exploring climate change psychology, museum-public engagement through exhibits, suitability of museums for climate-emotion work, and the potential for alternative museum approaches such as programming partnerships to create hope and foster action. She recommends research questions for the museum sector, and programmatic approaches for museums exploring support services for a public moving from grief and anxiety or despair, to hope.
\end{abstract}

Keywords: Hope, action, grief, climate change, museum.

\section{MUSEUMS AND CLIMATE HOPE}

Climate grief, and anxiety and despair are induced by experiencing climate change impacts or anticipating them. The feelings are socio-emotional evidence of an escalating social, economic, environmental and moral crisis on this planet. While the emotions of grief and despair have built to the scale of world health issues (World Health Organization 2014), they are felt individually, by our visitors, friends, neighbors, and the members of the communities where museums act. How can we museum professionals support the necessary, sometimes uncomfortable, and rather unexpected process of individuals confronting these negative emotions, and turn them toward positive feelings resulting in climate action and hope? Most commonly museums engage the public through exhibits. Can that be enough? A shift from traditional, chronological and scientific exhibits appears necessary, and the field is exploring new approaches, but we 
know too little yet to document these impacts. I propose that while we accelerate research on the ability of exhibits to help an overwhelmed public move to hope and possibly action, that we also explore programmatic approaches for faster results accessible to more of our publics. This exploration was triggered by a teaching experience. It demanded from me a blending of the personal with the professional to see new ways the museum field can connect with communities on this more personal dimension of climate impacts. This article is not a conclusion. It is a recommendation, primarily from an American perspective, and an invitation for readers to consider these new paths, explore them - perhaps with me, and certainly with peers, and then to share those paths with others.

\section{Climate grief comes to class}

Recently, in my museum studies course, a student read to the class an entry from her required daily journal: her partner was so depressed by the environmental degradation he saw as a forest manager, that she was gravely worried for his mental health. When I acknowledged that those of us in this work struggle with losses and the worry, she said it was more than that: her friends aren't planning to pay-off student loans, and they aren't saving for retirement. She isn't either, "Why bother?" she said. Other students agreed and one instantly shared a link to a recent article on climate grief and despair. Most of the others had read it and felt it reflected their fears. These students were new to climate study, but not to its threats.

My own despair surfaced and grew as I listened to them. It took a full ten days to restore my will, courage, and resources to shake that feeling. Conversations with my peers revealed similar states among their students. My email to a museum professional and conservation psychologist was returned with valuable resources and a virtual hug. Finding that corroboration and support among peers was a relief, and also a set of clues to how to be helpful to the students and others. Creating a path forward moved me past the despair to action, and back to hope. I expect that, increasingly, I and my colleagues in this work will repeat that process with peers, visitors, and communities for decades to come. In 2019 Dr. Michael E. Mann, Distinguished Professor of Atmospheric Science at Penn State, is quoted in an interview stating: "The greatest threat I see to climate action is the paralysis that comes from disengagement, disillusionment, despair" (Snow 2019). If this despair leads to paralysis, then we must pursue the alternative, because we need broad reaching action to address this crisis.

I believe museums can and should help individuals and communities turn climate grief and anxiety or despair into something positive. If the museum's role is to help communities thrive, and to do so through the thoughtful use of charitably-garnered resources and professionally-driven missions, then the responsibility to use these resources to address climate grief and anxiety is equal to the responsibility to address any critical community issues. So first we must determine how to help our communities move from negative emotions to positive and productive ones; then we must improve our understanding of how the positive emotions result in solutions. This remains less clear to me: does action foster hope or hope foster action? That relationship is the second conundrum; the first is that there is a need to address the pain and museums do not yet recognize their responsibility or power to do so. 


\section{Climate grief AND ANXIETy ARE AN UNDER-EXAMINED WORLD HEALTH ISSUE}

Though the impacts of climate change are unevenly distributed, much of the world's population commonly encounters climate change evidence; some directly, others indirectly. Increasingly mental health professionals and climate impact observers are identifying incidences of how the experience of climate events and the anticipation of the building disaster has mental health impacts. There is growing commentary on climate change as a mental health issue, and some developments on the clinical treatment of its impacts on the human psyche. Based on a study of anxiety and mood disorders after Hurricane Katrina, The World Health Organization's report on Gender, Climate Change \& Health identified the disproportionate impacts on women, and called for research on gender response to climate disasters and change (World Health Organization 2014: 11). The Intergovernmental Panel on Climate Change's Special Report on Global Warming of $1.5^{\circ} \mathrm{C}$ notes that there are not yet enough research health outcomes, including mental health, the impacts are badly understood (IPCC 2018). And the American Psychological Association (APA) report Mental Health and Our Changing Climate: Impacts, Implications, and Guidance explains that while "Americans are beginning to grow familiar with climate change and its health impacts," the connections with mental health are too rarely connected or examined. It notes the clear evidence of "stress, depression, and anxiety" among the public, and that there are growing "psychological responses to climate change, such as conflict avoidance, fatalism, fear, helplessness, and resignation". It concludes that this prevents the United States from acknowledging and resolving the causes of climate change, and from doing the work to help people develop psychological resilience to its threats (Clayton, Manning, Krygsman \& Speiser 2017: 4).

As socially-conscious organizations, responsible for contributing to the well-being of communities, museums have a responsibility to help the people with whom they interact to surface and understand these feelings, and to share with them ways to move toward greater comfort. This requires engagement with medical and psychological professionals and practices previously outside the museum domain but, I propose, increasingly necessary within it.

\section{Presentation of Solastalgia, Moral INJURY, ANXIETY AND DEPRESSION}

First, let us examine the emotional impacts of climate change, then we will consider how that intersects with museum work. Clinicians document themes of Solastalgia, moral injury, anxiety and depression in people experiencing the emotional impacts of climate change. Solastalgia, a term that describes the distress an individual feels when directly experiencing the impacts of environmental change on their home environment (Albrecht 2005: 45). Clinical psychologist Leslie Davenport, author of Emotional Resilience in the Era of Climate Change explains that moral injuries come from "an act of transgression that shatters or violates moral and ethical expectations" from, among other sources, a person's culture or beliefs, or strongly held rules for society (Davenport 2017: 107). Anxiety and depression are related to feelings of helplessness and hopelessness, with anxiety being a future-facing worry, and depression as focused on the past, perhaps because of lost places, experience or security, or for missed opportunities to change the future 
path. Those who suffer from these feelings may find them overlapping and compounding. They may feel overwhelmed by anger and frustration at the real or anticipated losses of places, experiences, and potential. They may find these paralyzing if they see no path to create sufficient change. This is where Mann's inaction and disengagement take hold. One important solution is to support the building, or rebuilding, of resilience. This resilience is the capacity of a person or community to recover from a shock to a system, whether an external or internal system, and emotional, social, or physical system, among others. This resilience creates the setting for recovering positive emotions, even taking action. When a person feels they have the "ability to influence events," they are able to find a meaningful path forward, and are ready to learn from both the good and bad experiences along the way, they can take action (Davenport 2017: 110).

\section{MUSEUMS AS LIKELY TREATMENT PARTNERS AND SETTINGS}

Davenport (2017) offers seventeen clinical recommendations for "treatment" of those who feel the grief, despair, etc. Of her examples for supporting individuals as they process these emotions and build a path to resilience, eight are immediately achievable in museum settings:

- provide safe spaces for exploration,

- facilitate inquiry into unexamined beliefs that interfere with regenerative work,

- encourage connections to the natural world,

- cultivate creativity in solutions,

- teach communication skills,

- validate grief,

- teach self-care, and

- model community involvement.
This is where museums can step in to provide services that align with their missions and, in the process, support the construction of hope, even action, prescribed by climate psychologists. Museums:

- are already identified as trusted, safe spaces for the public.

- are already spaces for individual and community healing after terrible national events or local disasters.

- have critical value as places for celebration and remembrance.

- often are already investing in building skills to develop empathy among staff, visitors and the public.

- have shown their willingness to take on inequality, injustice, diversity, equity, access, and physical and intellectual and emotional challenges and disabilities.

- ready people to become critical thinkers engaged in their communities.

Museum engagement with this part of the public is an important opportunity. Climate psycholgists are learning that climate grief and anxiety are a manifestation of a person's awareness of climate change, and that individual awareness and learning about climate change are necessary for beginning to build skills and foster necessary continued action. Researcher Thomas J. Doherty (2018) writes that "Ecological worrying is a normal and expectable behavior that has been correlated with pro-environmental attitudes and behaviors and with positive personality traits, such as openness and agreeableness" (253). These are our visitors. Colleen Dilenschneider, a United States museum-sector researcher reported in the National Awareness, Attitudes and Usage Study, that "a person who agrees strongly that the science indicating man's role in climate 
change is nearly twice as likely to visit a cultural organization [...] than someone who denies man's role as a primary contributor to climate change" (Dilenschneider 2017a). Research from The Yale Center on Climate Change Communication showed that in April 2020, 26\% of American adults were "very worried" about climate change (Leiserowitz et al. 2020). So, worrying, if correlated with positive climate values, aligns with opportunity for new thinking; people with positive climate values visit museums at nearly twice the rate as those without, and many of the people who visit museums are climate worriers. Museums can be confident that most of those who visit are aware of what is happening, are very likely experiencing climate anxiety and grief, or are susceptible to it because of their awareness of the topic. This awareness and emotion creates museums' opportunity for engagement.

Dilenschneider, and Susie Wilkening, have continually demonstrated that the public trusts museums, placing them among the very most if not the most trusted resources (Dilenschneider 2017b). More importantly, as trusted advisors, museums are expected to recommend desired behaviors. Susie Wilkening (2020) shared a datastory about museums and the COVID-19 pandemic that applies to the museums' role in the climate crisis as well.

We all need respite and places that can heal us emotionally, mentally, and physically. Whether through giving us a sense of purpose, exploring what it means to be human, gaining knowledge, or allowing us to escape [...] museum-goers believe museums play a key role here. (Wilkening 2020)

So, the climate-aware are museum visitors; many of them are the climate worriers. The worriers are often the ones who want to bring about change. This means some of our visitors would benefit from support for climateemotions. This is where I believe museums' work can make a difference but, as yet, we only partially understand what support is needed.

The National Network of Ocean and Climate Change Interpreters (NNOCCI) has been studying and actively assessing how we can improve the effectiveness of climate conversations. The 2015 NNOCCI five-year report indicates that by providing interpreters with knowledge about climate science and effective communication techniques, and creating a supportive network of NNOCCI members, the interpreters gain confidence in their ability to do this challenging work. And they do it better - the process contributes to "better understanding of climate change among the people they speak to. In turn those people are more likely to take action to solve climate change." (Fraser et al. 2015: 1) The report also notes, however, that though the practitioners reported feeling more hopeful, among their social contacts "It seems greater understanding of climate change was more strongly associated with action than hope" (Fraser et al. 2015: 8). What we know so far, is that hope is associated with agency and expansive thinking, which can galvanize action (Swim, Geiger, Sweetland \& Fraser 2018: 73). And we know that "Messages that instill hope in the audience can motivate commitment to engaging in action" (Swim et al. 2018:74). So, what is the relationship between action and hope? Does hope lead to action, or action lead to hope? Does it matter which comes first? The NNOCCI report says:

[...] there is growing evidence that participation in collective action can stimulate a general, long lasting positive psychological transformation within activists. Participation in collective action seems to strengthen identification with others and to 
induce collective empowerment. Feelings of social connectedness, empowerment, and efficacy emerging from the participation in collective action can feed into activists' positive, agentic self-definitions and nurture the conviction that change is possible. (Bamberg, Rees \& Schulte 2018)

This tells me that "which comes first - hope or action?" is the wrong question. "What is the relationship? may be the better query, with investigations of the degree of influence between them being equally valid. Perhaps the research question should be "What mix is optimal for hopeful messaging and cooperative action that fosters significant mitigation?" This is the body of research I believe museums can and should pursue alongside the climate and conservation psychologists.

\section{EXHIBITS AS THE EXPECTED ATTEMPT TO FOSTER ENGAGEMENT}

To date, the majority of research on museums' impact on visitor's response to climate change has been limited to exhibitions. These have been and continue to be the dominant approach to engaging the public on climate. In my experience, museum professionals have too little longitudinal information on how these experiences affect our visitors, or if exhibits are the best tools for bringing about climate engagement beyond exhibition visits.

In the US, early climate exhibitions were purely scientific, and found primarily at science centers and natural history museums. Often, the topic was treated as an addition to a chronological approach to examining Earth's history, not human history. This is true at both the National Museum of Natural History in Washington, DC., and the American Museum of Natural History in New York City. Both were recently reviewed and upgraded to confidently and explicitly address the science of climate change and human role in it. Both included some opportunities for selfreflection for the visitor, but no calls to action beyond examining personal practices (Sutton 2020). Such exhibits are common worldwide, what might be the evolution beyond these pragmatic approaches?

In 2018, in a natural history exhibit at the National Museum Cardiff the Youth Forum staged a "gallery takeover" No Môr Plastic (This name has a double meaning: môr means 'sea' in Welsh, so it can be read as 'No More Plastic' and 'No Sea Plastic'). They called it a museum intervention to raise awareness of and examine the issue of plastic pollution. It sprang from youth anger and frustration (Younan \& Jenkins 2020). In examining the collections to prepare for their project to create a display, the students discovered that a turtle which had been found dead on the beach in 1988, had been collected and then prepared for exhibit. The taxidermist found its stomach filled with plastic - from a life ended twenty years before ocean plastic awareness reached current heights. Let's be clear: addressing plastic pollution is, on the surface, an environmental issue more than a climate one, but the actions association with consumption, waste management, sourcing materials, and failure by those responsible, are directly in line with those issues related to climate. In part because of the frustration the youth see at the lack of adult intervention, and the students' worries for their own futures, this youth committee at the museum felt this story "needed to be told more loudly and visibly" in the exhibitions on the Ocean. As they prepared to do so, the students examined the options of taking a stand against ocean plastic. They concluded that the risk of the No Môr Plastic intervention to upset the public "was far outweighed by the need for immediate 


\section{SARAh W. Sutton}

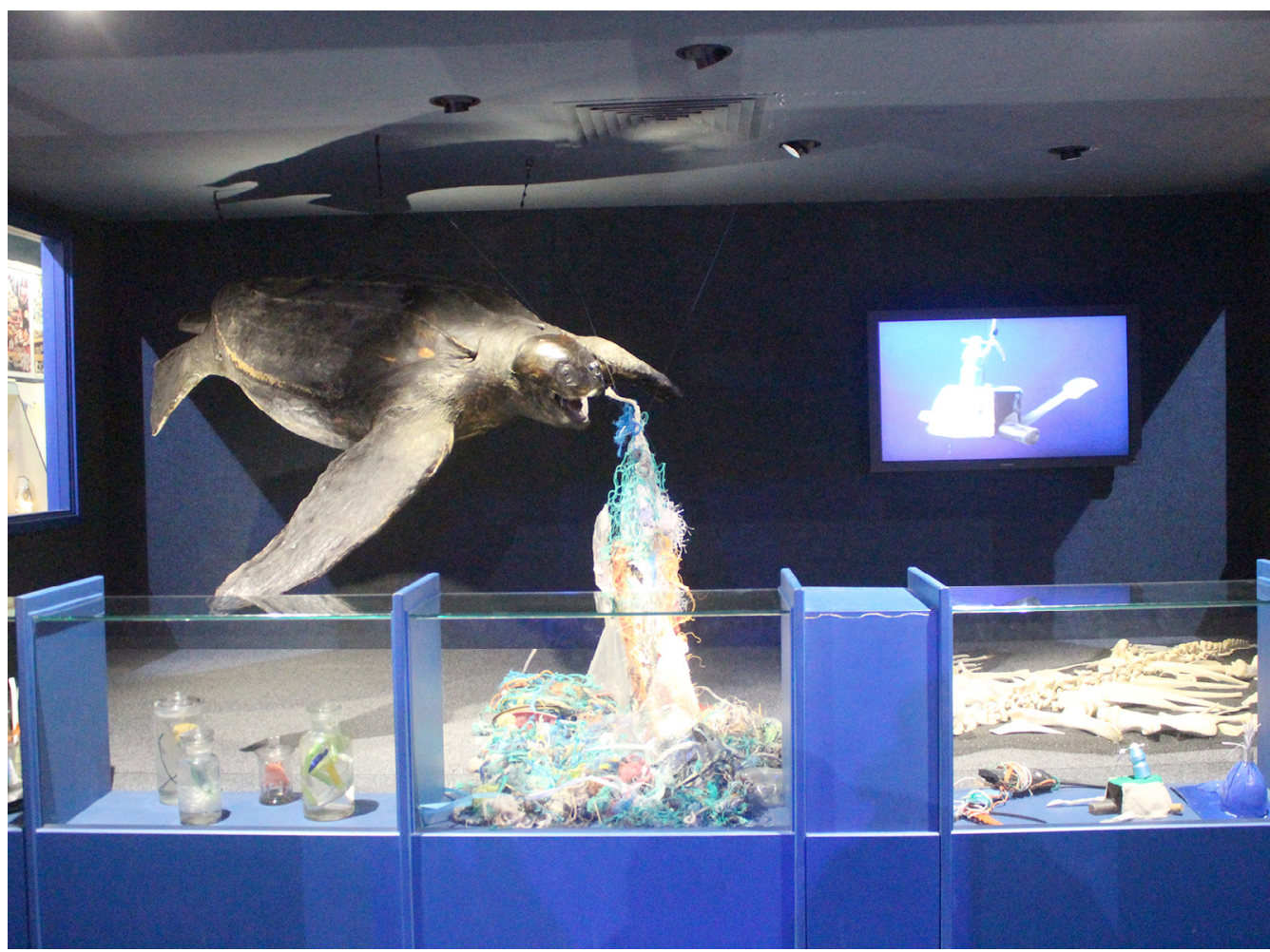

Fig. 1. Taxidermy sea turtle with plastic waste installation: Photo: Sarah Younan. The plastic intervention at Amgueddfa Cymru - National Museum Wales was supported by the National Lottery Heritage Fund's "Kick the Dust" initiative to enable youth-led projects in museums.

action on environmental issues" (Younan \& Jenkins 2020). They could not take a neutral stance, and indeed, felt the museum could not remain neutral on any issue. They went ahead with collecting beach plastic, cleaning and processing it as if it were new collections items, and then "temporarily littering" sea-life displays with the waste. They were right about it being worth any perceived risk: in the exhibit's reflection spaces and feedback board there was an "overwhelmingly positive" response to the intervention. This reflects current study in the US on museum neutrality in the face of contested issues. Dilenschneider's research shows that museums' tendency toward neutrality in the face of a polarizing issues compromises their authority for people on both sides of the issue. She writes "Recent happenings suggest that when an organization's mission is pinned against a politicized topic, standing up for your mission wins" (Dilenschneider 2019). Younan and Jenkins concluded that "audiences do want to engage with challenging themes in the museum environment, and that concerns around upsetting content should be weighed up against the positive impact that an activist 


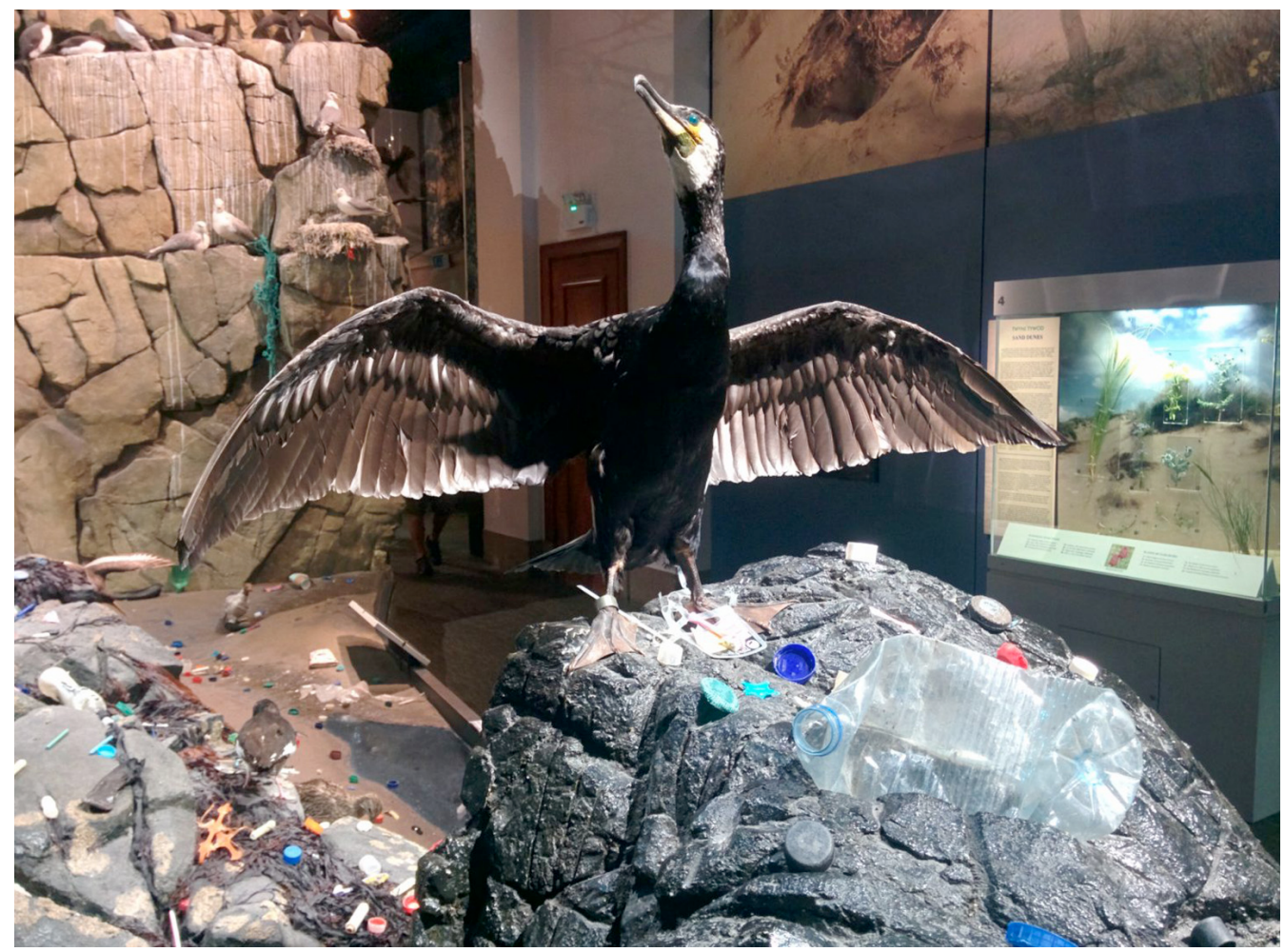

Fig. 2. Sea life diorama with plastic waste. Photo: Sarah Younan. The plastic intervention at Amgueddfa Cymru - National Museum Wales was supported by the National Lottery Heritage Fund's "Kick the Dust" initiative to enable youth-led projects in museums.

museum environment can have" (Younan \& Jenkins 2020).

Shiralee Hudson Hill (2020), an independent professional, has written about her experience curating the exhibit Anthropocene at the Art Gallery of Ontario in 2018, part of a series or exhibits and activities in partnership with three visual artists. Art exhibitions, particularly photography, have been the most common alternative approach to museum engagement on climate after natural history. Hudson Hill's experience reinforced her conviction that visual arts hold tremendous potential for encouraging people "to make personal connections with issues of planetary change. Because art activates emotions, memories, learning and meaning-making in the brain in unique and complex ways, it offers unique possibilities for artists and museums to forge pathways to engagement." (Hill 2020) Of the 128,644 visitors who commented on their experience with Anthropocene, twenty percent rated their experience as "superior" and fiftysix percent rated it "excellent". Yet many visitors also left the exhibition feeling worried (twentyfour percent) and saddened (twenty percent) 
by the artworks (Hill 2020). Is this a cause for alarm. Perhaps not.

Neuroscience research on public response to art engagement suggests this should not be cause for disappointment but evidence that the exhibit opened a path to creating individual change. The Peabody Essex Museum in Salem, Massachusetts, US, conducts biometric studies of visitor experiences to art exhibits. Its Neuroscience Initiative team has concluded that "Creating emotional reverberations in the galleries [...] is an important element to fostering visitor engagement and transformation. [...] the emotional intensity must be high whether or not the experience is a pleasant one" (Peabody Essex Museum 2020).

So aesthetic approaches appear to create a human emotional state prepared for transformation. Psychologist Davenport supports this thinking that attending to something in a special way creates openings that peoples' narratives would otherwise wall off: "By loosening our investment in our story, fresh perspectives and other feelings can naturally arise in the space that is created. This kind of self-inquiry cultivates a more balance and realistic view" (Davenport 2017). In a different setting but with similar emotional intensity, Thom van Dooren (2017) examined the aspect of "hope" in a curatorial and conservation effort: The Last Snail: Loss, hope and care for the future. He considered meanings of hope among conservationists working to protect species, specifically endangered Hawaiian tree snails. He was concerned that hope displayed as the action of caring can perhaps be a salve that limits further, greater action. In the end he concludes "The grounded and responsible hope that we need today, hope for a world still rich in biocultural diversities of all kinds, requires this kind of care for the future" (van Dooren 2017).
I met that last snail, George, Achatinella apexfulva. Standing in the room with him, knowing he was the last of a species, was sobering, discouraging, and, above all, sad. Standing in the room with him next to David Sischo, hearing him tell me about the cooperative actions of the Honolulu Zoo, The Bishop Museum and the Department of Land and Natural Resources to protect native species and their habitat, that gave me hope. (Sutton 2017). Davenport writes about moving through the grief process, converting "distress into passion for effective action. As we begin to express our thoughts, feelings, and behavior in alignment with our deepest values, we build tremendous strength and resilience. We find ways to attend to our own integrity despite what others may do or say" (Davenport 2017). This is where I believe museums can affect the most change. Driving away from my visit with George I felt profound grief, but as the road climbed through the mountains as I crossed the island, I could see the landscape they were protecting for other Georges, and I felt a renewed commitment to my own work to create the collaborations we need for change, with museums as the heart of those collaboration.

Davenport's mention of values suggests a line of research for examining the process and experience of museums' work to align values with environmental action, and how that degree of alignment can scale commitment and effort. The Nordic Museum in Seattle, Washington, US, routinely gathers visitor responses to queries in the gallery, particularly as the relate to the Nordic values of openness, social justice, innovation and connection to nature as expressed in the exhibits. In the Perspectives section in the last portion of its exhibits, the museum asks visitors to share responses to prompts as a way to gauge 
visitor reactions. In an exhibit that included references to climate change, nature, and open spaces, responses emphasized sustainability, respect for the environment, and the need for solutions to climate change. The staff considered this valuable for engaging nonscientists in the climate change discussion and for identifying "public interest and values that could be used more widely to inform policy maker of public interests" (Sutton 2020). This values-centered approach can be an example of how can museum exhibits, settings and programs create the opportunity for visitor selfexamination that embraces new information, fully-examines feelings, and clarifies values. First, though, we must understand better how to show that these transformations take place in our spaces through our agency.

\section{THE PROMISE OF MUSEUM 'TREATMENTS' FOR CLIMATE GRIEF AND DESPAIR}

These examples offer ideas, but the expanding climate crisis, and the anticipated expansion of mental health issues, calls museums to go far beyond exhibitions' attempts to create change. We must open more avenues. Because we understand that climate change, though global, is experienced locally, I propose that museums can offer their publics ways to address mental and planet health in their home communities. To do this, museums must actively listen to and observe the specific needs of their communities, and promote themselves as emotional partners for developing the needed interventions for helping the public move from climate despair to climate hope. Here are potentially valuable paths for partnering and providing experience that contribute to treatments for grief and despair:

Normalize mental health support and recognition of climate emotion through museums:
There are emerging examples of cultural institutions broadening their research and programmatic work to include understanding brain processes and mental health. I hope we can adopt this more widely. The Peabody Essex Museum, as described earlier, hired a neuropsychologist. The Montreal Museum of Fine Art hired a therapist who sees 1200 patients a year in closed-group art therapy all prescribed through the Canadian health system (Vartanian 2019). Rachel Tova Winer, a clinical psychologist working in Texas, leads Out Going, a therapy program that regularly visits museums and other cultural sites for group session (Winer 2019). Libraries are hiring what are now known as Library Social Workers, not to manage cases, but to help staff provide comfort, programs and access to resources for people experiencing homelessness, job loss, mental health issues, and any social concerns (Graduate School of Social Work 2018). Museums could choose to work with conservation psychologists, social psychologists, and the growing practice of climate psychologists, to provide direct service to staff and public. This work with mental health providers to offer outreach and onsite programming, may help reduce the stigma of accessing any mental health support, and can normalize the discussion of the mental health and climate emotions, just as museum professionals are trying to normalize conversation about climate change.

Offer climate support groups: Twelve-step programs are proven effective in other instances, Alcoholics Anonymous, for example. Some researchers report that similar programs in museums have had success (Simmons 2016). This makes a climate support group, with proper leadership, a legitimate program offering. Twelve-step programs are effective because they validate the emotional aspects and 
24 they engage affected individuals' values and hopes. The processes of creating connections among like-minded individuals and providing a safe place to share experiences and find social support align with what museums do already, and this approach clearly helps those experiencing grief, despair, anxiety and worry to move from isolation and despair to a sense of community and empowerment (Bamberg, Rees \& Schulte 2018).

Advocate for, and demonstrate, connecting people with nature: the separation of culture and nature is unnecessary and often harmful. Richard Louv (2017), author of The Nature Principle examined the health profession's "interest in the nature prescription". Medical professionals worldwide are increasingly embracing prescriptions for patients to spend time in nature (2017: 82). Museums' curated open spaces, programs with urban gardening and citizen science-in-nature as well as the field's public gardens, zoos and aquariums all support public engagement with nature. Both The Future of Our Pasts, the report from the International Council of Monuments and Sites (ICOMOS), and the United Nations Framework Convention on Climate Change's (UNFCCC) Sustainable Development Goals comment that these two realms are intertwined (ICOMOS 2019). It is reasonable to note that each is diminished by separation from the other, and that together they support human well-being. The "[...] integrated natureculture approaches can advance sustainability objectives by improving conservation outcomes, fostering bio- and cultural diversity, and supporting the well-being of contemporary societies and future generations in both urban and rural areas" (ICOMOS 2019: 3 ). These are places for celebrating nature in ways that strengthen engagement, and feelings of commitment and protection. This is where museums can leverage their physical resources for active engagement in public health and well-being.

Name museum work as climate action: Certainly, arts and humanities institutions can be allies for scientists. Professor Richard Primack's work on phenology, using Henry David Thoreau's journal comparative entries from his time at Walden Pond in the mid nineteenth century, is the touchstone for humanities documentation supporting scientific research (Primack 2014). The Concord Museum's 2013 exhibit Early Spring: Henry David Thoreau and Climate Change brought scientific research from the University of Boston to a local audience focused on history and literature. The public engagement activities and new school group programs proved extremely popular. (Sutton 2015: 141). But museums can also identify work in art and humanities settings as climate action when it documents action or the consequences of inaction. The photographs by Edward Morris and Susannah Sayler, taken from around the world for the traveling exhibit Canary Project Works on Climate Change (2006-2009), come to mind (Morris and Sayler 2017). It was my first visceral engagement with loss in a museum exhibit: seeing images of Venice underwater stopped my heart as I stood there with them in 2008. That experience expanded my awareness and strengthened my own commitment beyond local engagement just as Hudson-Hill's Anthropocene did for visitors. This is climate action work because it engages the public in understanding and connecting to climate change in ways that prepare them to take action.

Use historic achievements to model success against great odds: We can use the history of human kind's achievements to instill hope 
of an even greater achievement now. In the United States, citizens heeded Rachel Carson's warnings and made significant environmental progress in reducing chemical pesticide use and managing and monitoring water quality. Around the world countries have put humans on the moon and far out into space; and worked together to nearly heal the hole in the ozone layer. Local stories of overcoming disasters and local histories of adapting to changing weather or climate conditions provide examples of how others have succeeded and we can too. Consider He'eia fish pond on O'ahu in the state of Hawai'i. This ecosystem-driven, sustainable food site is over 60 acres of enclosed water at the edge of the island. It was built by the community with stone and coral, finished with wood and palm, to be a sustainable and shared food source in the community - 800 years ago.

Fifty years ago, it was damaged by a hurricane and abandoned. A decade ago, the community began its restoration. On three occasions I joined the staff of this small nonprofit, and some fifty of its hundreds of weekly volunteers, to restore this fish pond. We passed coral rocks hand-to-hand to rebuild its walls, cleared acres of invasive trees and then prepared them for construction of traditional structures. Now it is beginning to produce sustainably-harvested fish again. That experience was clear evidence that there is so much that can be accomplished, and that it can be a measurable accomplishment. Certainly, the experience was another example of action inspiring hope in me.

\section{Conclusion}

There is enough background research and individual examples of programs, research, action and exhibits to suggest a role for museums in addressing climate emotions - to diminish the negative and amplify the positive. I believe to advance public engagement on climate action through museums: 1) recognize that exhibitions cannot remain our primary public engagement on the human role and experience in climate change, and 2) expand partnerships with climate and conservation psychologists to radically advance hope.

First, exhibits. Their costs are high and their reach is limited. We must expand beyond this possibly over-valued tool. And, if we are to continue to use them, we must understand their true impacts on visitor action by conducting collaborative longitudinal studies. Time is too short to invest in these vehicles without maximizing their impact.

Second, establishing the roles and value of museums' partnerships with climate and conservation psychologists. If we actively engage in their research for public support, we can help us all understand the relationship between hope and action, and how museum experiences create the opportunity for visitor self-examination in ways that build hope, and how those experiences support the alignment of values with environmental action. Eventually we will identify the climate grief and anxiety interventions that are most closely aligned with growing climate hope.

Occasionally I revisit those feelings that overwhelmed me in talking with my students. Even a glimpse of the remembered worry reminds me that there is such value in museumclimate work to the present and future health of our communities and the world.

Ten days after that student's remark, I paused the original class syllabus. Studying climate grief and hope had renewed my faith in collective and cooperative action for healing and progress, and I was prepared to hear the full extent of their feelings. We each 
spoke about where we find climate grief and loss; this acknowledged shared feelings of that pain. We identified frustration and anger in our lives where others appear not to be listening or caring, and reviewed the climate communication skills we were learning during the semester for engaging with those who think differently or want to argue. We thought about how the class has helped each of us be more aware, feel more knowledgeable and less isolated, and feel more confident in our own abilities and more informed about where to put our efforts; and to value the collective action that helps us cope and has the greatest impacts for creating a thriving, just and healthy world. We did the things a museum can do, and it worked.

Now, grief and hope appear in the syllabus at the beginning of both my courses. Since that course ended, my resources on this topic have increased and my understanding continues to grow. The assignments and discussions emphasize the importance of allowing time and space to process - emotionally - all that they and I are encountering, whether as part of the class or in daily life.

I still require journaling because it revealed the difficulty to begin with, but now I ask students to complete the entries in nature or with it at their side. I ask them to use this time with nature to process what we are learning and sharing in class so that they can recharge themselves as wells of hope for themselves and for others.

And I will do the same.

\section{REFERENCES}

\section{Internet Sources}

Dilenschneider, Colleen 2017a. "People, Planet, Profit." In Colleen Dilenschneider: Know your own bone [Blog Post]. Retrieved from https:// www.colleendilen.com/2017/02/15/peopleplanet-profit-checks-and-balances-for-culturalorganizations/ (accessed October 2019).

Dilenschneider, Colleen 2017b. "People Trust Museums More Than News Papers.” In Colleen Dilenschneider: Know your own bone [Blog Post]. Retrieved from https://www.colleendilen. com/2017/04/26/people-trust-museums-morethan-newspapers-here-is-why-that-matters-rightnow- data/ (accessed October 2019).

Dilenschneider, Colleen 2019. "In Museums We Trust” In Colleen Dilenschneider: Know your own bone [Blog Post]. Retrieved from https://www. colleendilen.com/2019/03/06/in-museums-wetrust-heres-how-much-data-update/ (accessed October 2019).

Graduate School of Social Work 2018. "Library Social Work". Retrieved from https://socialwork. du.edu/news/library-social-work (accessed May 24 2020).

Peabody Essex Museum 2020. "PEM’s Neuroscience Initiative”. Retrieved from https://www.pem.org/ neuroscience-initiative (accessed May 24, 2020).

Simmons, Daisy 2016. "Sad about climate change? There's a support group for that." In Yale Climate Connections. Retrieved from https://www. yaleclimateconnections.org/2016/11/climatechange-support-group-launches/ (accessed October 2019).

Snow, Deborah 2019. "Why 'doomism' is part of the latest frontier in the climate wars." In The Sydney Morning Herald. Retrieved from https://www. theage.com.au/environment/climate-change/whydoomism-is-part-of-the-latest-frontier-in-theclimate-wars-20191018-p531y7.html (accessed October 2019).

Sutton, Sarah 2017. "Museums and the UN's Sustainable Development Goals (SDGs): The Hawaiian Land Snail Extinction Prevention Program." In Sustainable Museums [Blog Post]. Retrieved from https://sustainablemuseums. blogspot.com/2017/02/museums-and-uns- 
sustainable-development.html (accessed November 2020).

Vartanian, Hrag 2019. "A Museum Hires A Full-time Therapist." In Hyperallergic [Podcast]. Retrieved from https://hyperallergic.com/491210/amuseum-hires-a-full-time-therapist/ (accessed May 24, 2020)

Wilkening, Susie 2020. "Museums and the Pandemic: Data Story \#5" American Alliance of Museums \& Wilkening Consulting. Retrieved from: http://www.wilkeningconsulting.com/ uploads/8/6/3/2/86329422/museums_and_ the_pandemic_-_data_story_5_-_wilkening consulting.pdf (accessed May 2020).

Winer, Rachel Tova 2019. "Becoming OutGoing: How museums serve as social and psychological catalysts." In American Alliance of Museums Retrieved from https://www.aam-us. org/2019/10/31/becoming-outgoing-howmuseums-serve-as-social-and-psychologicalcatalysts/ (accessed May 24, 2020).

World Health Organization (2014). Gender, Climate Change and Health. Retrieved from https://www. who.int/globalchange/GenderClimateChange Healthfinal.pdf?ua=1 (accessed October 2019).

\section{LITERATURE}

Albrecht, Glenn 2005. "Solastalgia” A New Concept in Health and Identity. In Psychology, Activism and Nature. Retrieved from: (https://www.researchgate. net/publication/5820433_Solastalgia_The_ Distress_Caused_by_Environmental_Change accessed January 2021).

Bamberg, Sebastian, Jonas H. Rees \& Maxie Schulte 2018. "Environmental Protection through Societal Change: What psychology knows about collective climate action - and what it needs to find out". In Susan Clayton \& Christie Manning (eds.). Psychology and Climate Change: Human Perceptions, Impacts, and Responses. London: Elsevier, 185-208.
Clayton, Susan, Christie Manning, Kira Krygsman

\& Meighen Speiser 2017. Mental Health and our Changing Climate: Impacts, Implications, and Guidance. American Psychological Association. Retrieved from https://www.apa.org/news/press/ releases/2017/03/mental-health-climate.pdf (accessed October 2019).

Davenport, Leslie 2017. Emotional Resiliency in the Era of Climate Change: A Clinician's Guide. London: Jessica Kinsley Publishers.

Doherty, Thomas J. 2018. "Individual impacts and resilience.” In Susan Clayton \& Christie Manning (eds.). Psychology and Climate Change: Human Perceptions, Impacts, and Responses. London: Elsevier, 245-262.

Ebi, Kristie, Diarmid Campbell-Lendrum \& Arthur Wyns 2018. The 1.5 Health Report. Synthesis on health \& climate science in the IPCC SR1.5. World Health Organization. Retrieved from https:// www.who.int/globalchange/181008_the_1_5 healthreport.pdf?ua=1 (accessed October 2019).

Fraser, John, Kate Flinner, Lindsay Galvin \& Janet Swim 2015. "NNOCCI Impacts After Five Years". NewKnowledge.org and Pennsylvania State University. Retrieved from https://canvas.harvard.edu/ files/2532234/download?download_frd=1\&verifier=VXEN1iuoCIO2j0WJCQUjdyBeoeVLzsw9IHmfmhHk (accessed October 2019).

Hill, Shiralee Hudson 2020. "A Terrible Beauty: Art and Learning in the Anthropocene." Journal of Museum Education 45:1, 74-90. DOI: 10.1080/10598650.2020.1723357.

ICOMOS Climate Change and Cultural Heritage Working Group 2019. The Future of Our Pasts: Engaging cultural heritage in climate action. Paris: ICOMOS.

IPCC 2018. Special Report on Global Warming of $1,5^{\circ} \mathrm{C}$. Intergovernmental Panel on Climate Change. Retrieved from https://www.ipcc.ch/sr15/ (accessed October 2019).

Leiserowitz, Anthony, Edward Maibach, Seth Rosenthal, John Kotcher, Parrish Bergquist, 
Matthew Ballew, Matthew Goldberg, Abel Gustafson \& Xinran Wang 2020. Climate Change in the American Mind: April 2020. In Yale Program on Climate Change Communication and George Mason University: Center for Climate Change Communication. Retrieved from https:// climatecommunication.yale.edu/publications/ climate-change-in-the-american-mindapril-2020/ (accessed May 2020).

Louv, Richard 2012. The Nature Principle, Reconnecting with Life in a Virtual Age. Chapel Hill: Algonquin.

Morris, Edward \& Susannah Sayler 2017. “Object in view: The Canary Project: Photographs and Fossils." In Jennifer Newell, Libby Robin \& Kirsten Wehner (eds.) Curating the Future: Museums, communities and climate change. London: Routledge, Ltd., 206-210.

Primack, Richard B. 2014. Walden Warming: Climate Change Comes to Thoreau's Woods. Chicago: University of Chicago Press.

Sutton, Sarah 2015. Environmental Sustainability at Historic Sites and Museums. Lanham, MD: Rowman and Littlefield.

Sutton, Sarah 2020. "The Evolving Responsibility of Museum Work in the Time of Climate Change."
Museum Management and Curatorship 35:5, 618-635. DOI: 10.1080/09647775.2020.1837000.

Swim, Janet K., Nathaniel Geiger, Julie Sweetland \& John Fraser 2018. "Social construction of scientifically-grounded climate change discussions." In Susan Clayton \& Christie Manning (eds.). Psychology and Climate Change: Human Perceptions, Impacts, and Responses. London: Elsevier, 65-87.

van Dooren, Thom 2017. "The last snail: Loss, hope and care for the future." In Jennifer Newell, Libby Robin \& Kirsten Wehner (eds.) Curating the Future: Museums, communities and climate change. London: Routledge, Ltd., 145-152.

Younan, Sarah \& Jade Jenkins 2020. "Reality Check: Adding plastic to natural history." Journal of Museum Education 45:1, 42-51. DOI: 10.1080/10598650.2020.1723357.

Sarah W. Sutton, LEED-AP

Principal of Sustainable Museums, Washington, USA. https://sustainablemuseums.net/ sarah@sustainablemuseums.net 